Magyar Honvédség Egészségügyi Központ, Közegészségügyi-Járványügyi Intézet

\title{
A honvéd-egészségügyi alapellátó rendelök müködési mutatói a 2015. évi betegforgalmi adatainak elemzése alapján
}

\author{
Dr. Sótér Andrea alezredes PhD, \\ Dr. Meglécz Katalin orvos ezredes
}

Kulcsszavak: honvéd-egészségügyi alapellátó, betegforgalmi adatok, morbiditás

A szerzők tanulmányunkban elemzik honvéd-egészségügyi alapellátó (csapat-egészségügyi) rendelök alapfeladataként meghatározott gyógyító-megelőző alapellátásának, a 2015. évi adatait. A 82519 orvos-beteg találkozás a legtöbb esetben valamilyen akut ellátási igény, fertőzés és légúti megbetegedés miatt történt. Az állománykategóriák közötti elemzések differenciáltabb képet mutatnak a megbetegedésekröl. Míg a legfiatalabb, tanintézeti hallgatói állomány átlagosan 5 napot, addig a polgári állomány a háromszorosát, átlag 15 napot van távol a munkahelyétől, betegség miatt. A polgári beosztásúak körében a krónikus, főként szív, és érrendszeri megbetegedések ellátása áll az első helyen, amely a kiesett munkanapok számával párhuzamot mutat. A kórházban eltöltött napok száma a hivatásos állomány körében a legmagasabb, átlagosan 6 nap, a legkevesebb a tanintézeti hallgató csoportban, átlagosan 3 nap. A Magyar Honvédség személyi állományának magasabb szintü szakellátásában a polgári egészségügyi intézmények is részt vesznek, az összes szakorvosi ellátás $51 \%$-a, míg az összes fekvőbeteg ellátás $64 \%$-a, a honvéd-egészségügyi szakellátó rendszeren kívül valósul meg. A csapat-egészségügyi szolgálatok személyi infrastruktúrája évek óta igen kedvezőtlen képet mutat. 2015-ben a Magyar Honvédség 13 alakulatánál nem volt a katonaorvosi státusz betöltve, ami az előző évek pályaelhagyási tendenciáját erősíti. Az átlagosan egy orvosra jutó 1965 eset ellátása, illetve emellett a további csapat-egészségügyi alapfeladataik végrehajtása az ellátók teherbíró-képességének a határát jelzik. 
A Magyar Honvédség egészségügyi ellátórendszere - csakúgy, mint $\mathrm{Ma}$ gyarország egészségügyi ellátórendszere - kettős tagolódású, azaz alapellátásból és szakellátásból (járó- és fekvőbeteg szakellátásból) áll. Az ellátórendszer az eltérő állapotú betegek differenciált ellátását szolgáló és a fokozatosság (progresszivitás) elvén alapuló intézményrendszerre épül. Legalsó szintjén helyezkednek el a kapuőri funkciót amely biztosítja, hogy a magasabb szintü ellátást csak indokolt esetben vegyék igénybe a betegek - ellátó, az egészségügyi alapellátásért felelős csapat-egészségügyi szolgálatok. Békeidőszakban, a csapat-egészségügyi szolgálat alapfeladatai a következők [1]:

1. gyógyító-, megelőző- és gondozó munka (pl.: elsősegély, általános orvosi ellátás, gyógyszerellátás, szakrendelöi- és kórházi kezelésre, kivizsgálásra utalás, szürővizsgálatok végzése, magasvérnyomásos betegek gondozása, stb.);

2. közegészségügyi-járványügyi tevékenységek (pl.: fertőző betegek beés kijelentése, helyszíni ellenőrzések, járványügyi vizsgálatok);

3. harckiképzési, harckészültségi és mozgósítási feladatok egészségügyi biztosítása;

4. részvétel a személyi állomány egészségügyi kiképzésében és egészséges életmódra nevelésében.

Egy adott populációban a morbiditás monitorozásához - és ezzel együtt a betegségteher becsléséhez - alapvetően négyféle módszer áll rendelkezésre [2]:

1. Fekvőbeteg-intézetek adataira épülő regiszterek (pl. rákregiszter)

2. Lakossági egészségfelmérések (pl.: Országos Lakossági Egészségfelmérés-OLEF)
3. Fertőző betegségek kötelező jelentési és nyilvántartási rendszere (pl. Epidemiológiai Felügyeleti Rendszer és Informatikai Rendszer-EFRIR, pulmonológiai hálózat - köztük a TBC - éves morbiditási adatai)

4. Háziorvosi /alapellátási morbiditási monitorozó rendszer (pl. Háziorvosi Morbiditási Adatgyüjtő ProgramHMAP)

Tanulmányunk szempontjából a 4. csoportba tartozó adatgyüjtési módszerek relevánsak, melyeknek a világon kétféle változatuk terjedt el. Az egyik az esetalapú adatgyüjtés, amely minden egyes orvos-beteg találkozásról adatokat rögzít, a másik az úgynevezett sentinel jellegű adatgyüjtés, melynek során kijelölt egészségügyi szolgálatok célzottan egyegy konkrét betegségcsoportra vonatkozóan gyüjtenek adatokat (pl. influenza) [3].

A csapat-egészségügyi szolgálatok a rendelők személyi- és tárgyi infrastruktúrájáról, az alapellátás betegforgalmi adatairól (csapatorvosi ellátás igénybevételi adatai, szakrendelésre utaltak, fekvőbeteg ellátás keretein belül kezeltek, keresőképtelenség, megbetegedési adatok) évente jelentést terjesztenek fel a Magyar Honvédség Egészségügyi Központ - mint szakmai irányító - részére. Ez az adatszolgáltatás az esetalapú adatgyüjtéshez kapcsolódik, tehát minden egyes orvos-beteg találkozás során adatrögzítés történik. A betegforgalmi jelentés adatai az egészségügyi ellátórendszer kapacitásának megtervezéséhez, az ellátás megszervezéséhez, a betegségteher méréséhez és várható alakulásának becsléséhez, a haderővédelemhez ( $\mathrm{pl}$. prevenciós programok tervezéséhez) és a hadrafoghatóság nyomon követéséhez nyújtanak értékes információt. 
Cikkünkben a csapat-egészségügyi szolgálatok 2015. évi betegforgalmi jelentéseit elemezve ismertetjük az alapellátás igénybevételi adatait, a betegségteher állománykategória szerinti alakulását, valamint a jelenlegi ellátórendszer főbb problémáit, kihívásait.

\section{Módszerek, eszközök}

A vizsgálat elvégzéséhez a Magyar Honvédségen belül használt betegforgalmi jelentés adattábláit használtuk fel, melyeket összefüzve, egy adatbázist hoztunk létre. Az adatok elemzéséhez és a grafikonok elkészítéséhez a Microsoft Excel 2007 programot használtuk.

Az elemzés során az alábbi mutatókat határoztuk meg.

1. A betegségteher mérésére:

a) A morbiditás megoszlási viszonyszámainak kiszámítása, amellyel a betegségstruktúra állománykategória szerinti alakulását elemeztük.

b) A szakellátás igénybevételi adatainak elemzése, amely egyrészt az alapellátás vonatkozásában a defi- nitív ellátás mutatója, másrészt az alapellátás kompetenciáját meghaladó esetek gyakoriságáról tájékoztat.

c) Kórházi napok és keresőképtelen napok állománykategória szerinti elemzése, amelyből az egyes esetek súlyosságára következtethetünk.

2. A honvéd-egészségügyi alapellátórendszer leterheltségének mérése:

a) Személyi infrastruktúra alakulása, az egy orvosra jutó betegek és esetek száma.

\section{Eredmények}

\section{A honvéd-egészségügyi alapellátás igénybevételi adatai}

A 2015. évben az alapellátást biztosító csapatorvosi rendelők ellátási kötelezettsége 25272 före terjedt ki. Az ellátandók túlnyomó része (77\%) a hivatásos és szerződéses állomány tagjaiból került ki, $16 \%$ volt a polgári alkalmazottak (kormánytisztviselők és közalkalmazottak) aránya, 3\%, a hallgatóké és $4 \%$ az egyéb kategóriába tartozott.

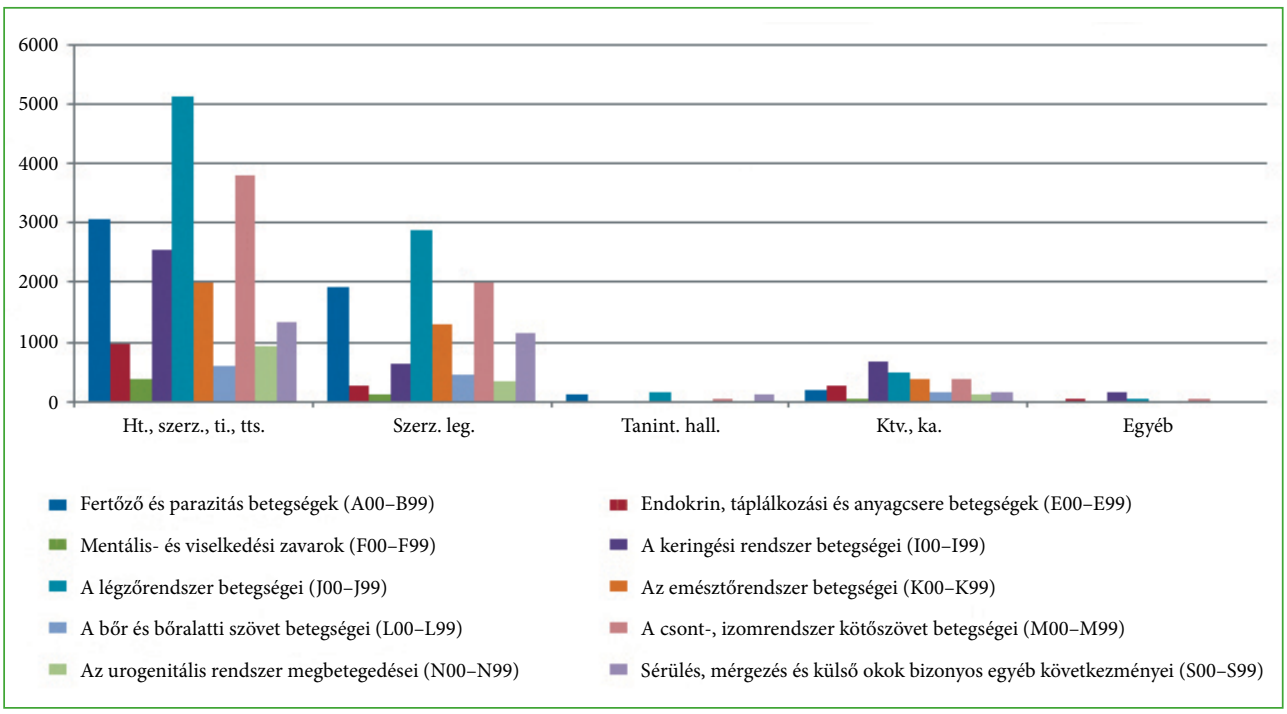

1. ábra. Morbiditási struktúra állománykategória szerinti alakulása (2015.) 
I. táblázat. Betegségstruktúra állománykategória szerinti mutatói a leggyakoribb megbetegedések tekintetében (2015)

\begin{tabular}{|c|c|c|c|c|c|}
\hline Megbetegedés (BNO) & $\begin{array}{l}\text { Hivatásos, } \\
\text { szerződéses } \\
\text { ti., alti. }\end{array}$ & $\begin{array}{l}\text { Szerzö- } \\
\text { déses } \\
\text { legénység }\end{array}$ & $\begin{array}{l}\text { Tanintézeti } \\
\text { hallgató }\end{array}$ & Ktv, ka. & Egyéb \\
\hline $\begin{array}{l}\text { Légzőrrendszer betegségei } \\
\text { (J00-J99) }\end{array}$ & (1.) $24 \%$ & (1.) $25 \%$ & (1.) $28 \%$ & (2.) $15 \%$ & (2.) $12 \%$ \\
\hline - Ebből heveny (J00-J22) & $70 \%$ & $65 \%$ & $23 \%$ & $67 \%$ & $81 \%$ \\
\hline $\begin{array}{l}\text { Csont-izomrendszer és } \\
\text { kötőszövet (M00-M99) }\end{array}$ & (2.) $18 \%$ & (2.) $18 \%$ & (3.) $10 \%$ & (3.) $12 \%$ & (2.) $12 \%$ \\
\hline $\begin{array}{l}\text { Fertőző és parazitás } \\
\text { (A00-B99) }\end{array}$ & (3.) $14 \%$ & (3.) $17 \%$ & (2.) $23 \%$ & $6 \%$ & $6 \%$ \\
\hline $\begin{array}{l}\text { Keringési rendszer } \\
\text { betegségei (100-199) }\end{array}$ & $12 \%$ & $5 \%$ & $1 \%$ & (1.) $22 \%$ & (1.) $34 \%$ \\
\hline $\begin{array}{l}\text { - Ebből magasvérnyomás } \\
(|10-| 15)\end{array}$ & $75 \%$ & $52 \%$ & $0 \%$ & $74 \%$ & $76 \%$ \\
\hline $\begin{array}{l}\text { Az emésztőrendszer } \\
\text { betegségei (K00-K93) }\end{array}$ & $9 \%$ & $11 \%$ & $4 \%$ & (3.) $12 \%$ & $7 \%$ \\
\hline $\begin{array}{l}\text { Sérülés, mérgezés és } \\
\text { külső okok bizonyos egyéb } \\
\text { következményei } \\
\text { (S00-T98) }\end{array}$ & $6 \%$ & $10 \%$ & (2.) $23 \%$ & $5 \%$ & $5 \%$ \\
\hline - Ebből sérülés (S00-T19) & $65 \%$ & $48 \%$ & $14 \%$ & $56 \%$ & $87 \%$ \\
\hline $\begin{array}{l}\text { Endokrin, táplálkozási és } \\
\text { anyagcsere (E00-E90) }\end{array}$ & $5 \%$ & $2 \%$ & $0 \%$ & $9 \%$ & (3.) $8 \%$ \\
\hline $\begin{array}{l}\text { - Ebböl cukorbetegség } \\
\text { (E10-E14) }\end{array}$ & $12 \%$ & $6 \%$ & $0 \%$ & $17 \%$ & $15 \%$ \\
\hline $\begin{array}{l}\text { Urogenitális rendszer } \\
\text { megbetegedései } \\
(\mathrm{N}-00-\mathrm{N} 99)\end{array}$ & $4 \%$ & $3 \%$ & $3 \%$ & $4 \%$ & $3 \%$ \\
\hline $\begin{array}{l}\text { Máshová nem osztályozott } \\
\text { tünetek (R00-R99) }\end{array}$ & $3 \%$ & $3 \%$ & $6 \%$ & $7 \%$ & $3 \%$ \\
\hline $\begin{array}{l}\text { Bör- és bör alatti szövetek } \\
\text { betegségei (L00-L99) }\end{array}$ & $3 \%$ & $4 \%$ & $2 \%$ & $5 \%$ & $6 \%$ \\
\hline $\begin{array}{l}\text { Mentális és } \\
\text { viselkedészavarok } \\
\text { (F00-F99) }\end{array}$ & $2 \%$ & $1 \%$ & $0 \%$ & $2 \%$ & $4 \%$ \\
\hline
\end{tabular}

Megjegyzés: ( ) az adott állománykategória betegségstruktúrájában elfoglalt hely

A tényleges éves betegforgalom 82519 eset volt, amelynek kb. 74\%-a (61 222 eset) új esetként került rögzítésre (az adott diagnózissal az adott évben először orvoshoz fordulók száma). Az igénybevétel átlaga 4 alkalom/fö/év volt, az igénybevétel állománykategória szerinti megoszlása nagyrészt megfelelt az ellátandók állománykategória szerinti megoszlásának.

\section{A megbetegedés (morbiditás) adatai}

A morbiditási adatok (betegségstruktúra, prevalencia, incidencia mutatók) pontos ismerete a katonai vezetés számára is fontos információkat szolgáltathat a hadrafoghatósággal, a harcképesség fenntartásával kapcsolatban. Tekintettel arra, hogy a jelentésben $\mathrm{BNO}$ szerinti 
bontásban csak az új esetek kerülnek jelentésre, az adatokból az állományra jellemző morbiditási struktúra becslésére van csak lehetőség. Az adatokból számított betegségstruktúra leginkább a csapatorvosi ellátás igénybevételi okáról tájékoztat az új esetek vonatkozásában. $\mathrm{Az}$ állomány morbiditási struktúráját leíró teljes keresztmetszeti kép elkészítéséhez prevalencia típusú mutatókra is szükség van (ilyen jellegü mutatókat az alkalmasság időszakos ellenőrzésekor végzett vizsgálati adatokból nyerhetünk). Az új esetekből incidencia mutató számítására van lehetőségünk, melynek segítségével az adott időszakra vonatkozóan (jelen esetben 1 év) egy adott betegség teljes populációban (jelen esetben ellátandók) való megjelenésének abszolút kockázatát tudjuk becsülni.

A csapatorvosi ellátás igénybevételi okairól - ezzel együtt az egyes állománykategóriákra jellemző betegségstruktúra alakulásáról - a Betegségek Nemzetközi Osztályozása (BNO) szerinti betegforgalmi adattáblák tájékoztatnak [4]. A morbiditási struktúrára vonatkozó eredményeket az 1. ábrán és az I. táblázatban foglaltuk össze.

$\mathrm{Az}$ 1. ábrán és az I. táblázatban látható:

- A hivatásos, szerződéses tiszti, altiszti, a szerződéses legénységi állomány és a tanintézeti hallgatók körében leggyakrabban a légzőrendszer betegségei (J00-J99) állnak, melyből a heveny betegség előfordulása a hivatásos állomány körében $70 \%$, a szerződéses legénységi állomány körében $65 \%$ és a tanintézeti hallgatók körében ugyanakkor $23 \%$.

- A másodikként a hivatásos, szerződéses tiszti, altiszti állomány és a szerződéses legénységi állomány körében 18-18\%os gyakorisággal a csont-izomrendszer és kötőszövet (M00-M99) betegségei jelennek meg, míg a tanintézeti hallgatók esetében a fertőző és parazitás betegségek (A00-B99) és a sérülés, mérgezés és külső okok bizonyos egyéb következményei (S00-T98) fordulnak elö 23-23\%-kal.

- A harmadik helyen a fertőző és parazitás betegségek (A00-B99) jelennek meg a hivatásos, szerződéses tiszti, altiszti állományra vonatkozóan 14\%-os és a szerződéses legénységi állománynál 17\%-os gyakorisági értékkel, míg a tanintézeti hallgatókra nézve a csont-izomrendszer és kötőszövet (M00-M99) betegségei állnak $10 \%$-kal.

A polgári (köztisztviselö, közalkalmazott és egyéb) állomány körében a következőképpen alakultak a megbetegedési arányok:

- Mindkét állománykategóriában az összes megbetegedés közül legnagyobb arányban (átlag 28\%) a keringési megbetegedés (100-199) fordult elö, melynek túlnyomó része (átlag 75\%-a) magasvérnyomás (110-115) betegség volt. Mindkét arányszám 2014. évhez képes növekvő tendenciát mutat.

- A köztisztviselő, közalkalmazotti állomány körében második leggyakoribb betegségcsoportok 15\%-os elöfordulással. Az egyéb kategóriába sorolt polgári állomány tekintetében második helyen a légzőszervi megbetegedések (J00-J99) mellett a csontizomrendszer és kötőszövet megbetegedései (M00-M99) szerepelnek 12-12\%-os gyakorisággal.

- A köztisztviselö, közalkalmazotti állomány körében elöforduló harmadik legnagyobb megbetegedési csoportok $12-12 \%$-kal fordulnak elő a légzőszervi megbetegedések (J00-J99) 
és az emésztőrendszer betegségei (K00-K93). Az egyéb kategóriába sorolt polgári állományra vonatkozóan a harmadik helyen a endokrin, táplálkozási és anyagcsere (E00-E90) szerepelnek 8\%-os előfordulással, melynek 15\%-a cukorbetegség (E10-E14).

A következtetések levonása előtt meg kell jegyeznünk, azt a tényt, miszerint számításainkat az összes feltüntetet betegségcsoporttal elvégeztük, a sorrendiségek megjelölésénél azonban szándékosan kihagytuk az egészségi állapot és egészségügyi szolgálatokkal való kapcsolatot befolyásoló tényezők betegségcsoportot (Z00-Z99), ami a legnagyobb arányszámmal jelent meg az összes állománykategóriánál, a tanintézeti hallgatók körét kivéve. Ez a BNO besorolás olyannyira általános és széles körü, valamint olyan gyakorisággal került alkalmazásra, hogy szakmai érvekkel nem alátámasztott statisztikai adatokat nyertünk volna. A kapott eredmények a valóságnak így is megfelelnek, mert az előfordulási gyakorisági sorrendek egy helyezéssel elörébb kerültek.

A betegségstruktúra elemzéséből megállapíthatjuk, hogy a katonai állomány vonatkozásában az első három leggyakoribb betegségcsoportban főként akut ellátást igénylő megbetegedések állnak (légúti betegségek, csont-izomrendszer betegségek, fertőző és parazitás megbetegedések,), de már megjelennek a keringési rendszer betegségek (elsősorban a magasvérnyomás betegség), az emésztőrendszeri betegségek, a sérülések, valamint az endokrin, táplálkozási és anyagcsere betegség. A polgári állomány körében - feltehetően a magasabb életkor miatt - előtérbe kerülnek a krónikus nem fertőző betegségek, kimagaslóan a keringési betegségek (elsősorban a magasvérnyomás betegség), azt követően a légúti betegségek, a csont-izomrendszer betegségek, az emésztőrendszeri betegségek és az endokrin betegségek.

A morbiditási adatokból tehát látható az életkor kedvezőtlen hatása a betegségteher növekedésére, a krónikus nem fertőző betegségek arányának emelkedésére, ami legszembetünőbb módon a keringési rendszer betegségeinek vonatkozásában érhető tetten. Éppen ezért különös jelentőséggel bírnak a hivatásos, illetve szerződéses állományba vétel előtti alkalmasság vizsgálatok, az életkor szerinti gyakorisággal az alkalmasság időszakos vizsgálata, melyek a premorbid állapotok korai felismerését és ennek következményeképpen a hatékonyabb komplex kezelés lehetőségét rejti magában.

\section{Szakellátás igénybevételi adatai}

Abban az esetben, ha az alapellátást felkereső betegek ellátása vagy a pontos diagnózis felállítása meghaladja az alapellátás kompetenciáját, az alapellátó a betegeket szakrendelőbe, vagy közvetlenül fekvőbeteg intézetbe utalja be.

A 2015. évi 82519 orvos-beteg találkozásból a szakrendelésre utaltak száma 13797 fó volt, az utalások 49\%-a (6712 fó) érintette a katonai szakrendeléseket, 51\%-a (7085 fö) polgári szakrendelésre került beutalásra. A csapategészségügyi ellátás definitív voltát látszik igazolni, hogy az összes rendelési megjelenés átlag $17 \%$-a volt szakrendelésre továbbutalva. A szakmai megalapozottságról - a helyes diagnózisalkotásról - tájékoztat, hogy az utalások átlag 3\%-ában fordult elö, hogy a szakrendelés a beutalón szereplö diagnózistól eltérő diagnózist állapított meg. A különböző szakrendelésre utalt esetek megoszlását állománykategória és intézménytípus szerint a 2. ábrán láthatjuk. 


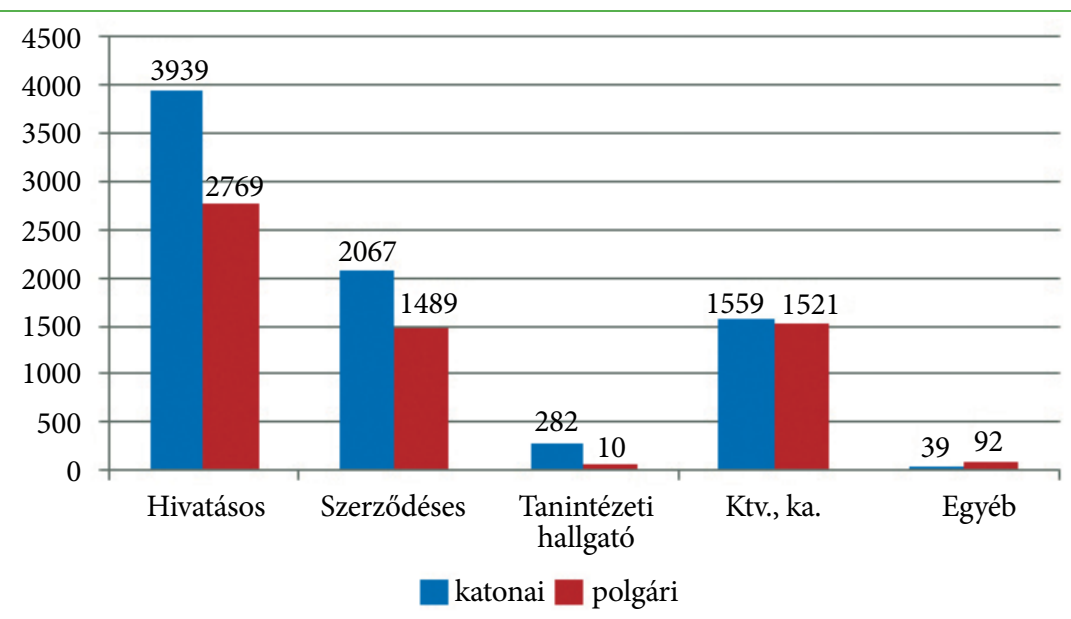

2. ábra. Szakrendelésre utaltak eseti megoszlása állománykategória és intézménytípus szerint (2015)

Az általános járóbeteg-szakellátás magában foglalja a betegnek fekvőbeteg-ellátást nem igénylő krónikus betegsége esetén a folyamatos szakorvosi gondozást is.

A tercier prevenció feladata megelözni a betegség késői komplikációit vagy visszatérését. Ennek legfőbb eszköze a gondozás. A II. táblázatban a járóbetegszakellátásban gondozásban részesülő betegekről szolgáltatott adatokat foglaltuk össze. Az MH BHD rendelöiből csak a gondozottak számáról van adat, a gon-

II. táblázat. Járóbeteg-szakellátásban gondozásban részesülő betegekről (2015)

\begin{tabular}{|l|c|c|c|}
\hline Gondozási ok & $\begin{array}{c}\text { Gondozottak } \\
\text { száma }\end{array}$ & $\begin{array}{c}\text { Gondozáson } \\
\text { megjelent }\end{array}$ & $\begin{array}{c}\text { Korlátozással } \\
\text { alkalmas } \\
\text { minősítésű }\end{array}$ \\
\hline Légzörendszer betegsége & 119 & 94 & 9 \\
\hline Keringési rendszer betegsége & 691 & 665 & 72 \\
\hline $\begin{array}{l}\text { Vér és a vérképző szervek } \\
\text { betegsége }\end{array}$ & 44 & 52 & 0 \\
\hline Emésztőrendszer betegsége & 83 & 83 & 4 \\
\hline $\begin{array}{l}\text { Csont,- izomrendszer,- } \\
\text { és kötöszövet betegsége }\end{array}$ & 165 & 121 & 81 \\
\hline $\begin{array}{l}\text { Endokrin, táplálkozási,- } \\
\text { és anyagcsere betegsége }\end{array}$ & 189 & 175 & 15 \\
\hline \multicolumn{1}{|c|}{ ezen belül cukorbetegség } & 78 & 78 & 1 \\
\hline Börgyógyászati betegség & 27 & 28 & 4 \\
\hline Daganatos betegség & 26 & 23 & 4 \\
\hline Mentális,- és viselkedészavarok & 34 & 27 & 0 \\
\hline Az idegrendszer betegsége & 21 & 18 & 14 \\
\hline Egyéb megbetegedés & 194 & 1459 & 204 \\
\hline Gondozottak összesen & & & 5 \\
\hline
\end{tabular}


dozáson megjelentek és a korlátozással alkalmas minősítéssel rendelkezők létszámadatairól nincs, valamint a KNBSZ sem szolgáltat a gondozottjairól adatot, így a MH BHD által gondozottak adatai nem szerepelnek a II. táblázatban. 2015. évben a csapatorvosi rendelők ellátási körébe tartozók $11 \%$-a részesült gondozásban, vagyis közel minden tízedik ellátottnak volt krónikus betegsége.

$\mathrm{Az}$ adatok tükrében a három leggyakoribb gondozási ok: a keringési rendszer betegsége, az endokrin, táplálkozási-, és anyagcsere betegség (amelyből minden második cukorbetegség), valamint a csont, izomrendszer, és kötőszövet betegsége.

\section{A fekvőbetegellátás adatai}

A 2015. évben a csapatorvosi rendelőkből a Magyar Honvédség Egészségügyi Központba utaltak száma 762 fö volt, a felvettek száma 325 fö, míg polgári kórházakba összesen 1376 föt utaltak és 594 föt vettek fel. A szakmai megalapozott- ságról tájékoztat, hogy az utalások és a felvételre kerülők számában jelentős eltérés nem mutatkozik, az utaltak 43\%ban felvételre kerültek. Az állomány kategóriák szerinti beutalások és felvételek arányaiból megállapítható, hogy a katona (és hallgatói) állomány közel $2 / 3$ része (64\%) a polgári fekvőbeteg intézetekben került ellátásra. A fekvőbeteg ellátásba felvett esetek súlyosságáról az ellátás időtartama (kórházi napok száma) tájékoztathat. A kórházi ápolási napok száma összesen 4592 nap volt.

$\mathrm{Az}$ átlagos kórházi tartózkodás időtartamát napokra számítva állománykategória szerinti bontásban megállapítható, hogy a tanintézeti hallgatók átlagosan 3 napot, a szerződéses legénységi állomány 4 napot, a hivatásos és szerződéses tiszti, ill. altiszti állomány átlagosan 6 napot, míg a köztisztviselök, közalkalmazottak átlag 8 napot tartózkodtak a kórházban. A polgári alkalmazottak hosszabb ápolási napja a magasabb átlagéletkorból adódó nagyobb betegségteher, vagy a krónikus ellátás iránti igény jelzője lehet.

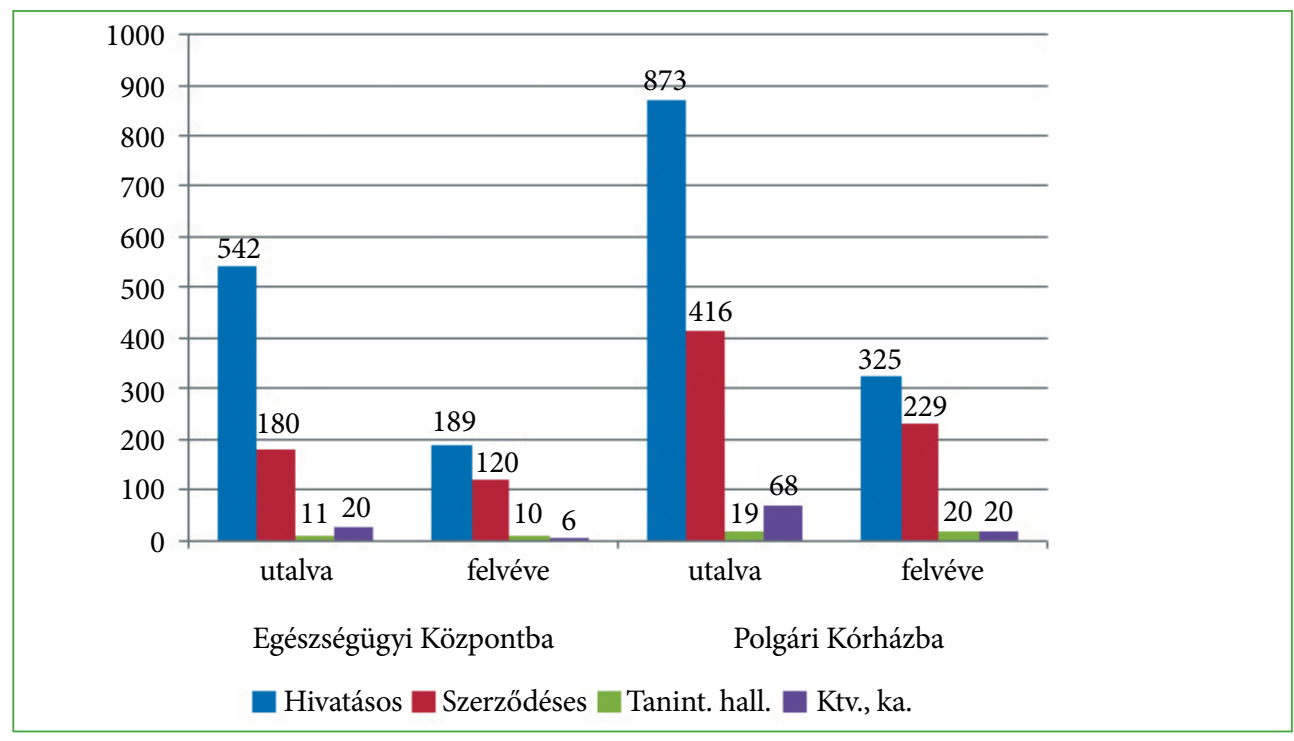

3. ábra. Fekvőbeteg ellátásba utaltak és felvettek száma állománykategória szerinti bontásban (2015) 


\section{Keresőképtelenség adatai}

A keresőképtelenség elnevezés a katona állomány esetében az egészségügyi szabadságot, a civil állomány esetében pedig a táppénzt jelenti. A keresőképtelen esetek száma a 2015. évben összesen 18351 eset volt, az egészségügyi szabadságon/táppénzen eltöltött idö összesen 149194 (!) nap volt. A keresőképtelen esetek 96\%-a és a keresőképtelen napok 93\%-a a katona állományt érintette (hivatásos, szerződéses tiszt, altiszt és szerződéses legénységi állomány). Ha megvizsgáljuk a keresőképtelenség átlagos hosszát állomány-kategóriánként, akkor a következő sorrendet kapjuk: tanintézeti hallgató (átlag: 5 nap), szerződéses legénység és hivatásos, szerződéses tiszt, altiszt (átlag: 8-8 nap) és kormánytisztviselő, közalkalmazott (átlag: 15 nap).

\section{Csapategészségügyi szolgálatok személyi infrastruktúrája}

A csapategészségügyi szolgálatok személyi ellátottsága évek óta jelentősen elmarad a kívánatostól. 2015. évben a katonai helyek feltöltöttségi mutatója
$66 \%$ volt, azonban a tényleges feltöltöttség 57\%-os. Ez a kedvezőtlen tendencia évek óta fennálló problémaként van jelen. Különösen rossz a helyzet a tiszti állomány vonatkozásában, ahol a tényleges feltöltöttség 38\%-ot mutat. Szinte valamennyi alakulat esetében problémát jelent, hogy az orvosi beosztást évek óta nem tudják katonával betölteni, így a feladatot közalkalmazottal vagy szerződéses jogviszonyban álló munkavállalóval láttatják el. 2015-ben 3 olyan alakulat volt, ahol egyáltalán nem volt orvos (MH 1. HTHE, MH 34. BLKMZ és MH AA), 2 olyan alakulat, ahol a csapatorvosi beosztásból tartósan távol tartózkodnak (MH 93. PSVVZ, MH BHK), amelynek következtében nem történik orvosi ellátás és 7 olyan alakulat (MH 5. BILDD, MH 12. ALRE, MH 25. KGYLD, MH 37 MüE, MH 64. BSZJLE, MH PBRT, MH ARB), ahol az orvosi tevékenységet szerződéssel foglalkoztatott orvos látja el. (Megj.: Azon alakulatok esetében, ahol pszichológussal rendelkeznek, a segélyhely parancsnoki beosztást a pszichológus látja el.) Ezek alapján a kritikus csapatorvosi feltöltöttség 12 alakulatot érint.

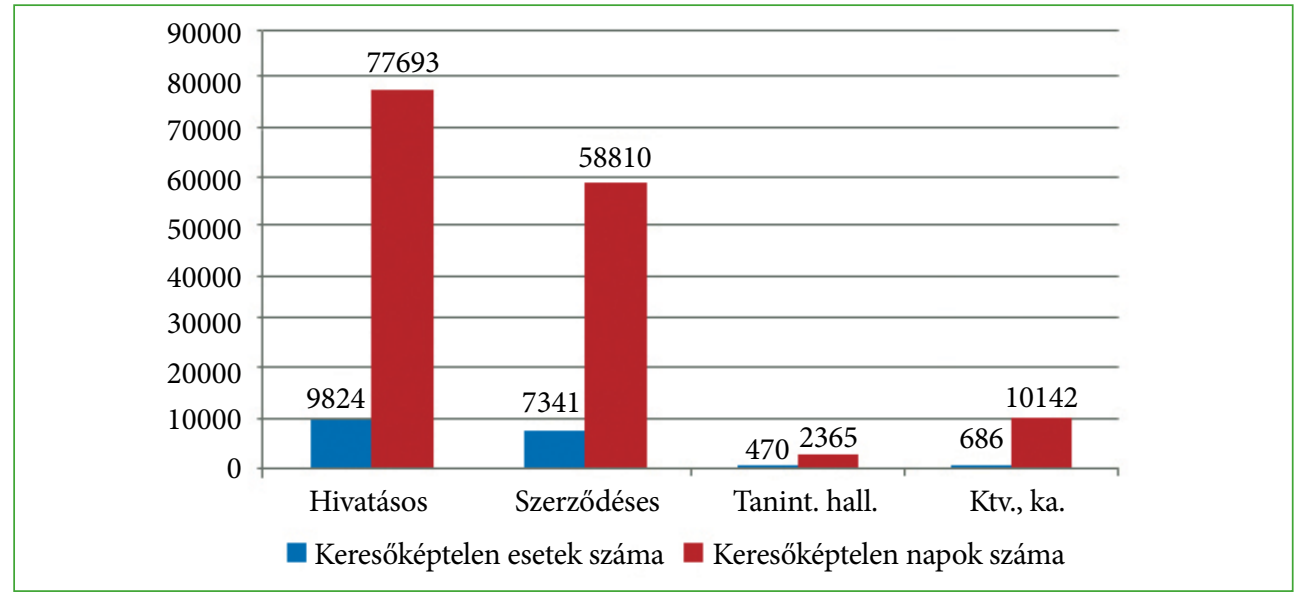

4. ábra. Keresőképtelen esetek és napok számának állománykategória szerinti alakulása (2015) 
A folyamatos képesség- és kapacitásvesztésnek kitett csapategészségügyi szolgálatok jelenleg még rendelkeznek egy szakmailag magasan képzett, átlagon felüli missziós tapasztalattal rendelkező, pozitív értelemben kiszelektálódott - magasan kvalifikált - személyi állománnyal, amely szinte erején és lehetőségein felül képes az egészségügyi haderővédelmi tevékenységek ellátására, a személyi állomány egészségének, testi épségének megóvására. Ugyanakkor az üres beosztások feltöltésének nehézsége, valamint az utánpótlás megoldatlansága miatt az egészségügyi haderővédelem "első frontvonala” az utóbbi években jelentősen meggyengült, ami tetten érhető a kedvezötlen feltöltöttségi mutatókban. Az állomány leterheltségét tovább fokozta a Magyar Honvédség tömeges bevándorlás okozta válsághelyzettel összefüggő (IBH, HF, KA) feladatok egészségügyi biztosítása, amely az alakulatok tényleges feltöltöttségi mutatóját nézve (38\%), komoly kihívást jelentett a mindennapi tevékenységek ellátása mellett.

\section{Összegzés}

A morbiditási (megbetegedési) adatok folyamatos gyüjtése, (monitorozása) és elemzése, lehetőséget ad az egészségügyi szakembereknek az ellátórendszer kapacitásának megtervezésére, az ellátás megszervezésére, optimalizálására, az egyes megbetegedésekből adódó betegségteher mérésére, várható alakulásának becslésére. Tanulmányunkban a csapategészségügyi szolgálatok 2015. évi betegforgalmi jelentéseinek elemzését végeztük el, két fontos kérdéskört érintve. Egyrészt az alap- és szakellátás igénybevételi adatai alapján következtetéseket vontunk le a személyi állományra jellemző betegségteher alakulásával kapcsolatban, másrészt a csapategészségügyi szolgálatok személyi infrastruktúrájának túlterheltségére hívtuk fel a figyelmet. A két kérdéskör egymással összefügg. Az alap- és szakellátás igénybevételi adatai, az állománykategóriák szerinti morbiditási struktúrák alakulása alapján igazolódott, hogy az életkor elörehaladtával a betegségteher növekvő tendenciát mutat, ami a közeljövőben - a nyugdíjrendszer kedvezőtlen változásának következtében kezelhetetlen problémát fog jelenteni a csapategészségügyi szolgálatok számára, amennyiben személyi infrastruktúrájuk fejlesztése nem történik meg. A folyamatos képesség és kapacitásvesztésnek kitett csapategészségügyi szolgálatok jelenleg még rendelkeznek egy olyan személyi állománnyal, amely szinte erején és lehetőségein felül képes az egészségügyi haderővédelmi tevékenységek ellátására, azonban a rendszer tovább már nem terhelhető. A probléma kezelése nem halogatható, a csapategészségügyi szolgálatok humán infrastruktúrájának fejlesztése ismét a katona-egészségügy megkerülhetetlen problémájává vált. Elkerülhetetlen a csapategészségügyben dolgozók számára is egy olyan életpálya perspektíva létrehozása, amely a feltételek (munkakörülmények, elöremenetel, képzés, juttatások, versenyképes jövedelem-illetményreform) megvalósítása révén, a fiatal katonaorvosok és egészségügyi szakdolgozók számára versenyképes alternatívát nyújt nemcsak a polgári élet, de a nyugat-európai országok nyújtotta karriermodelljéhez képest.

\section{Irodalom}

[1] Csapathadtáp szakutasítás az állandó harckészültség időszakára (htp/16), IV. rész: A személyi állomány egészségügyi ellátása, Magyar Honvédség kiadványa, 1990. 
[2] Donaldson, R.J., Donaldson, L.J.: Assesing the health of the population: Information and its uses. In.: Essential Public Health Medicine. Kluwer Academic, London, 1993.

[3] Széles Gy., K. Fülóp Ildikó, Bordás I., Ádány R.: A krónikus nem fertőző betegségek okozta morbiditás alakulása Magyarországon a HMAP és a GYOGYINFOK adatai tükrében In: Ádány R. (szerk): A magyar lakosság egészségi állapota az ezredfordulón, Medicina Könyvkiadó Rt., Budapest, 2003, 43-73.

[4] Betegségek Nemzetközi Osztályozása (BNO) http://www.gyogyinfok.hu/forum/BNO/index.asp

\section{Lt.Col. Andrea Sótér PhD, Col. Katalin Meglécz MD}

\section{The operational indicators of the military primary health care providers based on an analysis of patient traffic data for 2015}

In this article the indicators of the military unit medical centre are being presented from the year 2015, mainly focusing on the primary health care which had been defined by their primary duty. Most of the cases from the total 82519 derived from acute medical attention, including infections and respiratory diseases. The analysis on the personnel categories shows a more differentiated picture on illnesses. Among civilian per- sonnel lingering illnesses, especially vascular lesion are of frequent occurrence that comes together with the increasing time of absence from work. Compared to the youngest, military students who are absent from their workplaces 5 days a year on average, the civilian miss 15 days due to illness. The hospital treatment days also corresponds to this data. In favour of the higher level of specialist care provided for the personal ranks of the Hungarian Defence Forces the civil health care facilities also take part. $36 \%$ of all professional medical provision and $64 \%$ of in-patient care is taking place out of the Hungarian Defence Forces Health Centre's system.

The personal infrastructure of the unit medical centres has been showing an unfavourable image for years. In 2015 seven corps of the Hungarian Defence Forces were lacking a troop physician. For a troop physician who needs to take care of 1965 cases on average, besides living up to his or her other basic duties can end up in reaching the end of their bearing capacity.

Keywords: military unit medical centre, patient turnover data, morbidity

Dr. Sótér Andrea alez. PhD 1134 Budapest, Róbert Károly krt. 44. 